\title{
Non-dairy plant-based milk products as alternatives to conventional dairy products for delivering probiotics
}

\author{
Amal Bakr SHORI ${ }^{1 \star}$ (D), Ashwag Jaman AL ZAHRANI ${ }^{1}$
}

\begin{abstract}
Dairy products are important to the human diet and are one of the four essential food groups. Conventional fermented cow milk products possessed a variation of bioactive components that enhance the human body's physiological processes. However, traditional milk products can be replaced by non-dairy plant-based milk which is produced mainly from fruits and seeds such as soy, coconut, almond, rice, peanut, lupin, cashew, and hemp. Fermented plant-based milk is the outcome of intense bacterial activity of the starter cultures, leading to the production of lactic acid and biologically active compounds that adding nutritional and physiological value. In addition, the growth and viability of probiotics in plant-based milk are depended on several factors such as milk composition, fermentation process, type of probiotics, storage time and temperature, acidity, and packages. Therefore, this review focuses on the growth and viability of probiotics in fermented plant-based milk products during fermentation and refrigerated storage.
\end{abstract}

Keywords: viability; probiotics; plant-based milk; fermentation; soy milk; coconut milk.

Practical Application: Plant-based milk could be used to replace traditional dairy products and improve human health.

\section{Introduction}

Dairy products are considered to be good for health (Lee et al., 2020). They are one of the four essential food groups (Shori et al., 2018). Furthermore, the beneficial health effects of consuming these products have been shown in many studies (Lucatto et al., 2020; Eor et al., 2020; Hadjimbei et al., 2020; Pena et al., 2021). Nowadays, as the popularity of being "vegan" is increasing, traditional milk products can be replaced by plant-based dairy which is produced mainly from nuts and cereals such as soy, almond, rice, oat, and coconut milk (Shori, 2013a). Several plant-based dairy products have a long tradition in both Eastern and Western cultures and available widely in the market (Bernat et al., 2014). Although some plant milk products contain low protein and calcium, plant milk substitutes are used to replace cow's milk in the diet because of low allergy and intolerance issues, lactose-free, cholesterol-free, and low-calorie (Mäkinen et al., 2016). This may lead to increased consumer awareness and subsequently a rise in purchase levels (Jeske et al., 2018). Actually, these products 'marketing campaigns attempt to equate the healthiness of these substitutes with the original dairy product. In addition, previous studies have reported a therapeutic relationship between vegetable milk and diseases such as cancer, atherosclerosis, and inflammatory diseases with a good source of antioxidants (Bernat et al., 2014).

The fermentation of plant-based products is one of the most traditional methods for food preservation. It improves the sensory attributes of the final products as well as nutritional quality by reducing the content of sugars and enhancing the levels of thiamine, niacin, lysine (Jeske et al., 2018; Rasika et al., 2020). Now, more than five thousand various fermented food products are consumed by people around the globe (Ryan et al., 2020; Balthazar et al., 2021). Moreover, fermentation enhanced the digestion of the proteins in boiled soybean by $45 \%$ which affected human health. This is due to the increase in the essential amino acids (Ketnawa \& Ogawa, 2019).

Plant-based milk can be preserved by lactic acid fermentation which results in organic acid production and antimicrobials components (e.g., acetaldehyde and diacetyl; Chinsembu et al., 2015). Fermentation also improves the nutritional value of milk by increasing amino-acids, vitamins as well as therapeutic values such as anti-microbial, anti-tumor, anti-carcinogenic, and immunomodulation activity (Tangyu et al., 2019; Grom et al., 2020; Costa et al., 2020).

Today, demand for probiotic plant-based milk products is growing due to consumer's awareness of potential health advantages since probiotics enhance the balance and structure of microbiota and the protection against pathogenic species (Panghal et al., 2018). To assure the health benefits of fermented plant-based milk products, probiotics should meet the minimum level requirement for probiotic bacteria between $10^{6}$ and $10^{7} \mathrm{cfu} / \mathrm{mL}$ until the expiry date (Shori et al., 2018). Therefore, this review focuses on the growth and viability of probiotics in fermented plant-based milk products during fermentation and refrigerated storage.

\section{Probiotics and health effects in plant-based milk products}

Probiotics have been researched extensively for their health benefits. The Food and Agriculture Organization and the World 
Health Organization define probiotics as "live microorganisms which when ingested in enough amounts improve the health of the host (Hill et al., 2014; Shori et al., 2020). Efficacious probiotics must-have essential properties as follows: strong stability under storage and distribution conditions, must be non-pathogenic, non-toxic, sustainable in the host body, effective adhesion, resistant to low $\mathrm{pH}$ and bile salts in the gut, and should have good activity with beneficial effects on the host (e.g., improved immunity; Shori, 2021; Zendeboodi et al., 2020).

A previous study has indicated that fermented almond milk by lactic acid bacteria possesses antioxidative properties due to phenolic contents which may minimize oxidative stress-related diseases such as atherosclerosis, coronary heart disease, and cancer (Wansutha et al., 2018). Similar results have shown that the fermentation of soy milk increased antioxidative, ACE inhibitory, antibacterial, and anti-inflammatory effects as compared to unfermented soy milk (Shori, 2013b; Singh et al., 2020; Sadeghi et al., 2020). In addition, Miraghajani et al., (2019) showed a strong relationship between intake of fortified soy milk with $L$. plantarum and improvement of renal function for type 2 diabetic kidney disease, where consumption of probiotic soymilk led to a substantial decrease in the levels of renal function biomarkers cysteine $\mathrm{C}(\mathrm{Cys}-\mathrm{C})$ and inflammatory adipokine progranulin (PGRN) levels compared with the soy milk without probiotics. Fermentation of soy milk by the riboflavin-producing strain Lactobacillus plantarum CRL 2130 has prevents experimental colitis induced by trinitrobenzene sulfonic in a murine model (Levit et al., 2017). In addition, the fermented brown rice by Aspergillus oryzae has been reported to suppress inflammation and has the ability to prohibit the chemical carcinogenesis of the colon (Tasdemir \& Sanlier, 2020).

\section{Type of plant-based milk}

Healthy food supplies are becoming an ever-present problem for both consumers and companies alike due to the concern of feeding an increasing number of people each year. Therefore, plant-based dairy alternatives have been used for decades, and day by day the sensory attractiveness increases the acceptability of plant-based dairy (Jeske et al., 2018). In addition, plant-based dairy sales in the U.S. have grown 61\% from 2012 to 2017 (Mintel Press Team, 2018) achieving $\$ 1.9$ billion by Good Food Institute (2019). Non-conventional dairy substitutes of plant origin have been developed including soybean, almond, oat, coconut, rice, hemp, peanut, and cashew (Clay et al., 2020).

\subsection{Soy milk}

Soy milk provides proteins of great quality with low-cost production. In addition, it has a good level of kcal $(52 / 100 \mathrm{~g})$, proteins $(3.9 \mathrm{~g} / 100 \mathrm{~g})$, fats $(2.4 \mathrm{~g} / 100 \mathrm{~g})$, saturated fatty acids $(14 \% / 100 \mathrm{~g})$, mono-unsaturated fatty-acids $(21.6 \% / 100 \mathrm{~g})$, and poly-unsaturated fatty-acids $(63.5 \% / 100 \mathrm{~g})$ as compared to cow milk (Mazumder \& Begum, 2016). Previous studies have investigated that protein-rich soy products could reduce total cholesterol, low-density lipoproteins (LDLs), and triglycerides (Weiße et al., 2010). In addition, fermented soy products have been found to be effective in reducing the symptoms of diabetes mellitus, blood pressure, heart attacks, and cancer-related complications (Jayachandran \& Xu, 2019).

\subsection{Coconut milk}

Coconut milk has been used as a non-dairy substitute since 2010. It contains nutritious properties (i.e. carbohydrate, lipid, proteins, and potassium) and therapeutic values such as antioxidant activity (Daramola et al., 2016). In addition, coconut milk has an average of $70 \mathrm{kcal} / 100 \mathrm{~mL}$ compared to cow milk that has up to $150 \mathrm{kcal} / 100 \mathrm{~mL}$ (Katz, 2018). The calcium content in coconut milk is about $4 \%$ of daily calcium needs. In addition, it is enriched with vitamins and minerals such as vitamin $\mathrm{C}, \mathrm{E}, \mathrm{B} 1$, B3, B5, B6, iron, and phosphorus. Coconut milk contains $17 \%$ of saturated fats. However, these fats are easily metabolized by the body and almost $87 \%$ of these fats are saturated with lauric acid (44\%), followed by caprylic and capric acids (13\%). The main saturated fat with lauric acid is also found in mother's milk and has been shown to promote brain development and bone health (D’Amato et al., 2012; Paul et al., 2020).

\subsection{Almond milk}

The almond contains many nutrients, phytochemicals, and fatty acids which tremendously reduce cardiovascular risk (Manzoor, 2017). Almond milk was discovered in the early '90s and has no lactose, cholesterol, or saturated fat. Almond milk is suitable for people suffering from lactose intolerance and contains low calorie ranges from 30-60 kcals/ $100 \mathrm{~mL}$. Moreover, it is cheaper than cow milk and contents $3.0 \%$ ash, $3.4 \%$ fats, $1.7 \%$ proteins, and $4.5 \%$ carbohydrates (Manzoor, 2017). Almond milk supplies about $20 \%$ of vitamin E, $4 \%$ of riboflavin, and $2 \%$ of iron. In addition, other minerals such as calcium, magnesium, phosphorus, zinc, and potassium have been found in almond milk (Vanga \& Raghavan, 2018). It also acts as antioxidants, anti-inflammatory, antihyperlipidemic, antitumor, reduces platelet aggregation or change for blood clots, and enhances the immune system (Barreira et al., 2008; National Institutes of Health, 2008).

\subsection{Rice-milk}

Health-wise, there are no added benefits of consuming rice-milk, it is, however, considered the most hypoallergenic when compared to all the other plant-based milk. Rice-milk is extracted from boiled brown rice and brown rice starch, it has a thin consistency and no fiber (Wongthaweewatana et al., 2021). Despite rice-milk content less protein than cow's milk (only $1 \mathrm{~g}$ per $8 \mathrm{oz}$. cup) and a small amount of natural calcium, the rice-milk products available in the market are fortified with calcium and vitamins (i.e., A, D, and B12; Bridges, 2018).

Un-malted brown rice flour contains $7.10 \%$ protein, $1.26 \%$ fat, $1.05 \%$ ash, $1.17 \%$ fiber, and $89.42 \%$ carbohydrate (Abou-Dobara et al., 2016). However, the average chemical composition of rice-milk was as follows protein $(0.6 \%)$, carbohydrates $(10.6 \%)$, sugar $(4.0 \%)$, fat $(1.0 \%)$, and sodium (0.051\%). Abou-Dobara et al., (2016) reported that rice-milk promoted immunity and possessed antimicrobial activity due to the presence of selenium and magnesium. 


\subsection{Peanut milk}

Peanut milk is a yellow liquid with almost no fat and high protein content. It is prepared by grinding raw peanuts with water (1:6) for $30 \mathrm{~min}$ and the $\mathrm{pH}$ is adjusted to 9.0 before remove the fat using a cream separator (Arya et al., 2016). Peanut milk can be fermented by lactic acid bacteria to produce a beverage (Kadam \& Salunkhe, 1989). Although peanut milk is not popular, it is used extensively in low-income countries to overcome severe malnourishment and physical health. It has high mineral content, proteins, non-soluble fibers, and fatty acids such as linoleic, oleic acid, and phytic acids. In addition, peanuts are found to be enriched with p-coumaric acid which is known to be beneficial as antioxidants (Bansal et al., 2016). Phenolic compounds such as resveratrol, phenolic acid, flavonoid, and phytosterol are present in peanuts and reported to prevent the absorption of cholesterols from the food (Arya et al., 2016).

\subsection{Hemp milk}

Hemp milk is a natural beverage with high nutritional value. It is made by mixing hemp seeds with hot water then milled until the required consistency is reached and thereafter cooled down and this technique is carried out to extend the product shelf life (Curl et al., 2020). Hemp seeds contain protein such as arginine with several sulfur-rich proteins (20-25\%), carbohydrates (20$30 \%)$, insoluble fiber (10-15\%), oil (25-35\%), vitamins such as vitamin $\mathrm{A}$, and minerals, particularly phosphorous, potassium, magnesium, sulfur, calcium, iron, and zinc (Ustun-Argon, 2019). Hemp seeds have been reported to possess diverse biological activity such as antioxidant activity and lowering blood pressure (Aluko, 2017). In addition, Szparaga et al. (2019) have concluded that hemp milk could be a good carrier for probiotic bacteria such as Lactobacillus casei subsp. rhamnosus.

\subsection{Lupin milk}

Lupin is widely used in the preparation of plant-based milk (Afolabi et al., 2018). Lupin milk is prepared by grinding lupin seeds with hot water for $5 \mathrm{~min}$ at high speed to get homogenized lupin milk and filter the slurry through a cheesecloth before coole-down (Elsamani et al., 2014). It has protein content (30\%), dietary fiber content (16\%), and fat content (6\%). In addition, lupin seeds have $33 \%$ and $18 \%$ of the recommended daily intake of thiamine and riboflavin, respectively (Oliveira et al., 2014). They have also large concentrations of polyphenol, carotenoid, phytosterol, tocopherol, and peptide with antioxidants, antimicrobials, anti-cancer, and anti-inflammatory activities (Khan et al., 2015). There is an increase in the demand for lupin-rich food products due to low glycemic index and higher protein content, and thus are beneficial for obese and diabetic patients with hypertension (Al-Saedi et al., 2020). In addition, the lactic fermentation of lupin milk to produce yogurt and ice cream has been previously reported (Jiménez-Martínez et al., 2003; Elsamani, 2016).

\subsection{Cashew milk}

Cashew milk is prepared by milling cashew nuts with water $1: 3(\mathrm{w} / \mathrm{v})$ ratio and the resultant slurry is filtered by using cheesecloth (Manzoor et al., 2017). The cashew nut milk products can serve as a vegetable protein source $(23 \%)$ with the potential of reducing the incidence of protein-energy malnutrition (Nair, 2010; Bruno et al., 2019; Oyeyinka et al., 2019). It is known as a rich source of essential fatty acids (44\%) and unsaturated fats $(82 \%)$. Cashew nuts are increasingly being consumed for functional benefits beyond their nutrition (Shori et al., 2022). The health benefits of cashew nuts are lowering the cholesterol level in the blood, controlling diabetes and coronary heart disease risk, maintaining healthy bones, and preventing high blood pressure (Tola \& Mazengia, 2019).

\section{The growth and viability of probiotics in plant- based milk products}

\subsection{Soymilk}

Recently, soy products have gained much attention as probiotic carriers. The nutritional value of fermented soymilk products differs depending on the kind of probiotic strain such as lactic acid bacteria (LAB). In addition, the presence of oligosaccharides, amino acids, and peptides in soymilk could enhance the growth and viability of probiotics (Farnworth et al., 2007; Šertović et al., 2020). The previous studies have documented the effectiveness of soy milk as a good substrate for the growth of probiotic and LAB strains (Table 1). Myagmardorj et al., (2018) have reported that soymilk increased the viable cell count of Lactobacillus fermentum BM-325 to $12.6 \log \mathrm{cfu} / \mathrm{mL}$ during 20 hours of fermentation. Seven strains of Lactobacillus spp (L. helveticus V3, L. rhamnosus NS6, L. rhamnosus NS4, L. bulgaricus NCDC 09, L. acidophilus NCDC 15, L. acidophilus NCDC 298, L. helveticus NCDC 292) in fermented soymilk have been studied by Hati et al., (2018). The viable cell counts of all the seven strains ranged between 6-9 $\log \mathrm{cfu} / \mathrm{mL}$ for 24 hours at $37^{\circ} \mathrm{C}$. In addition, the viability of $L$. casei PLA5 was significantly $(\mathrm{p}<0.05)$ increased by 1.24 and $1.09 \log \mathrm{cfu} / \mathrm{mL}$ in fermented soymilk supplemented with maltodextrin and fructooligosaccharides; respectively (Kumari et al., 2018). This is possibly attributable to its ability to produce various glycosyl hydrolases that hydrolyses maltodextrin and fructooligosaccharides to glucose for growth (Liong \& Shah, 2006; Silva et al., 2018). Similar results were observed by (Yeo \& Liong, 2010).

Soymilk kefir-based functional beverage significantly increased the viability of L. bulgaricus and Streptococcus thermophiles during 28 days of storage (Silva et al., 2018; Table 1). Similar results have been demonstrated in fermented soymilk and black bean milk with kefir grains (Liu \& Lin, 2000; Lim et al., 2019). Fermented soymilk with FOS in the presence of L. plantarum, L. acidophilus, or L. rhamnosus was investigated by Mishra \& Mishra, (2013). The viability of L. plantarum and L. acidophilus was significantly enhanced ranging between $14-12 \log \mathrm{cfu} / \mathrm{mL}$ during 28 days at $4{ }^{\circ} \mathrm{C}$ whereas the VCC of L. rhamnosus was reduced to $9.51 \mathrm{log}$ $\mathrm{cfu} / \mathrm{mL}$. However, the viability of L. rhamnosus in binary and/ or mixture with L. plantarum and L. acidophilus was improved in fermented soymilk with FOS. This finding is consistent with Horáčková et al. (2015) and Yi et al. (2020) who have indicated that mixed strains tend to be more effective than pure culture. The growth and viability of probiotics in fermented soymilk 


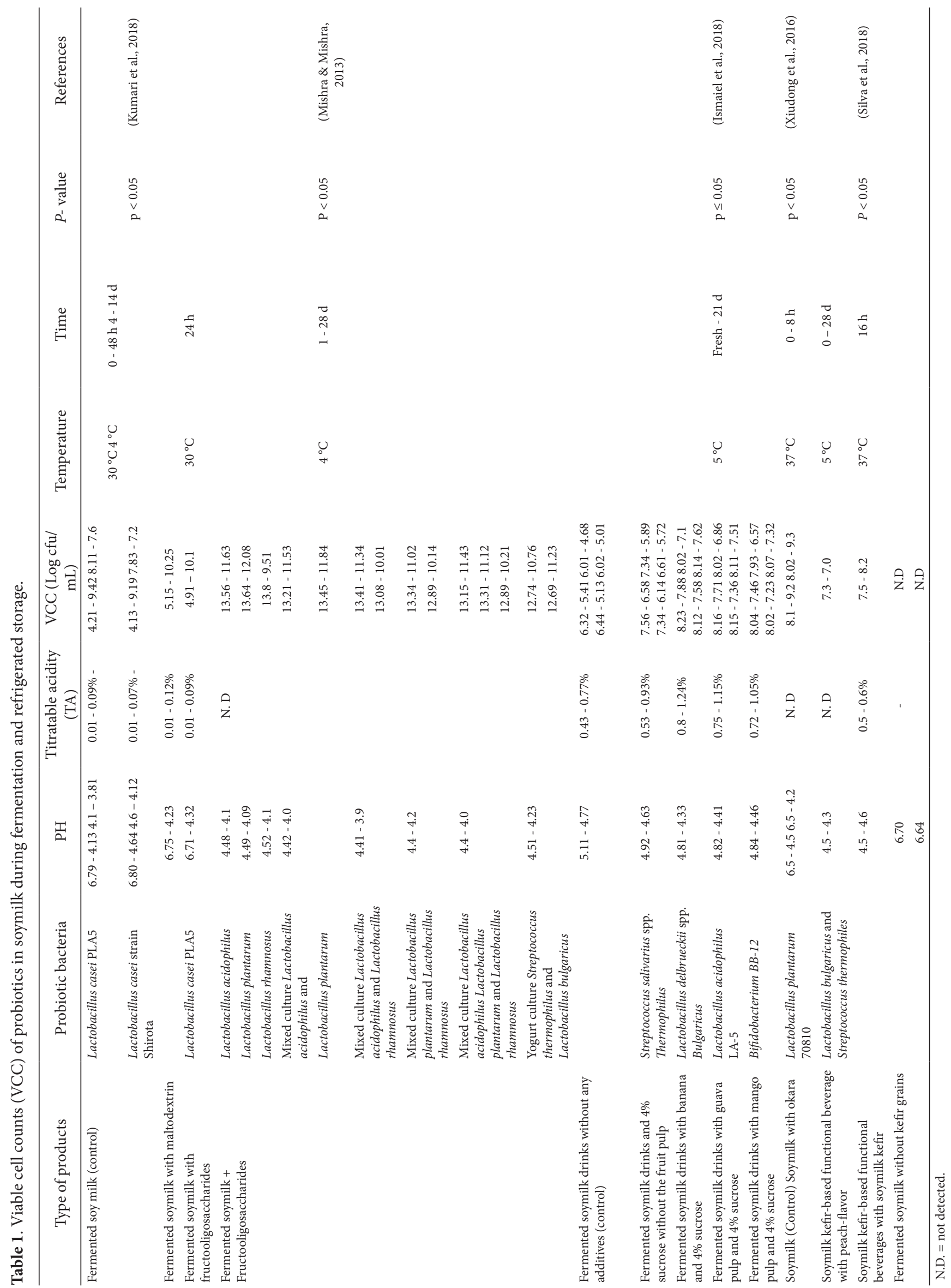




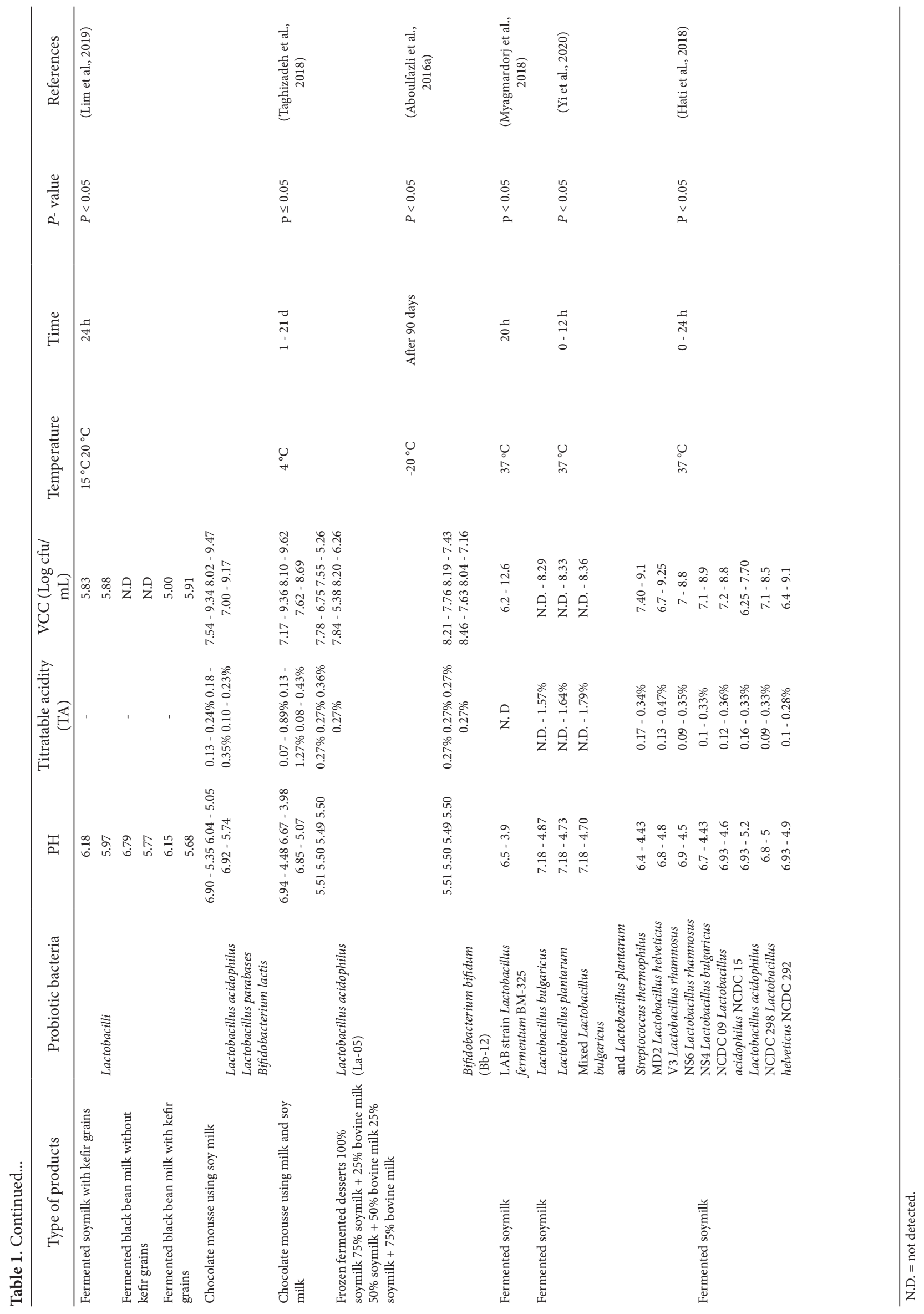




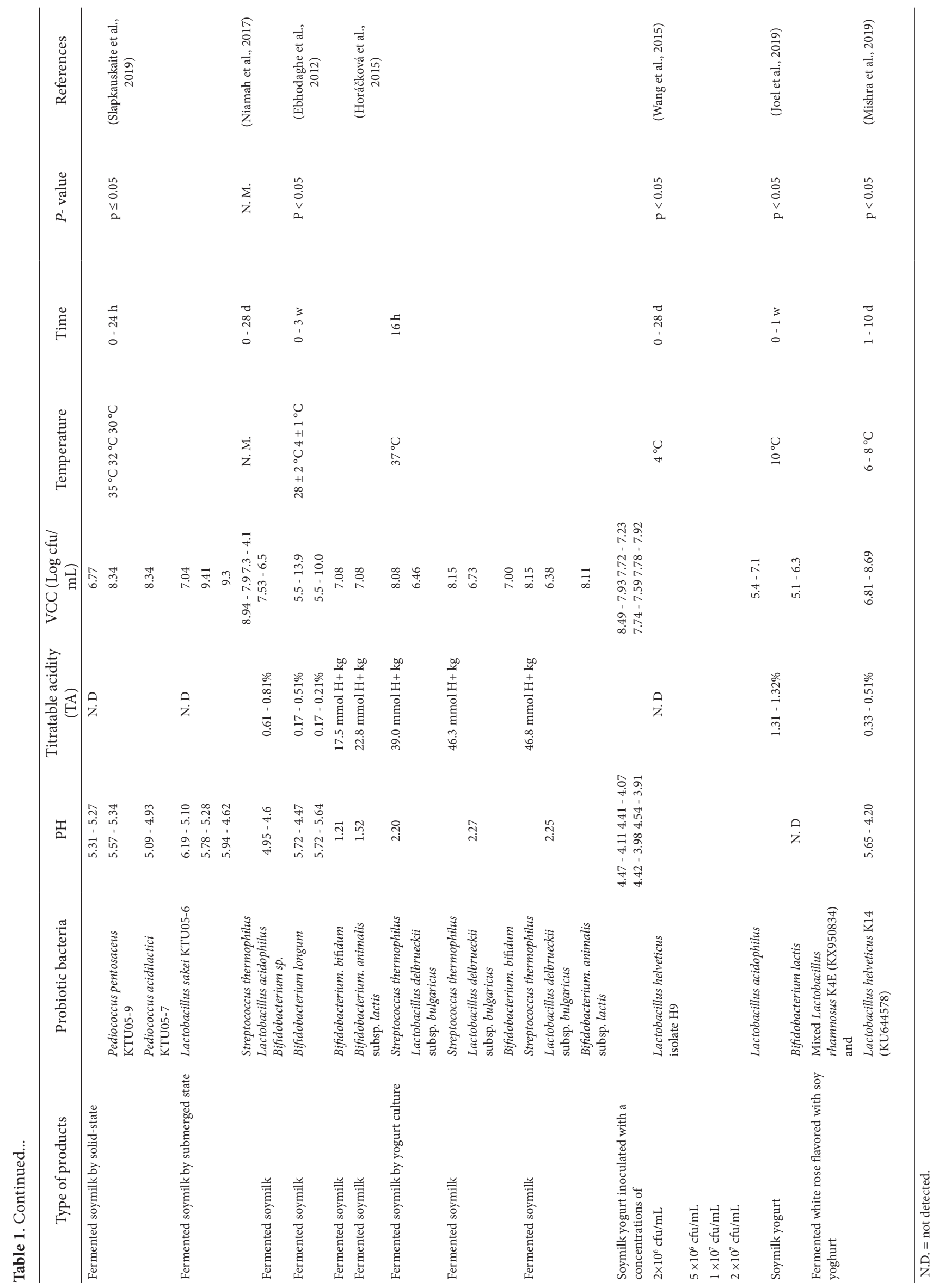




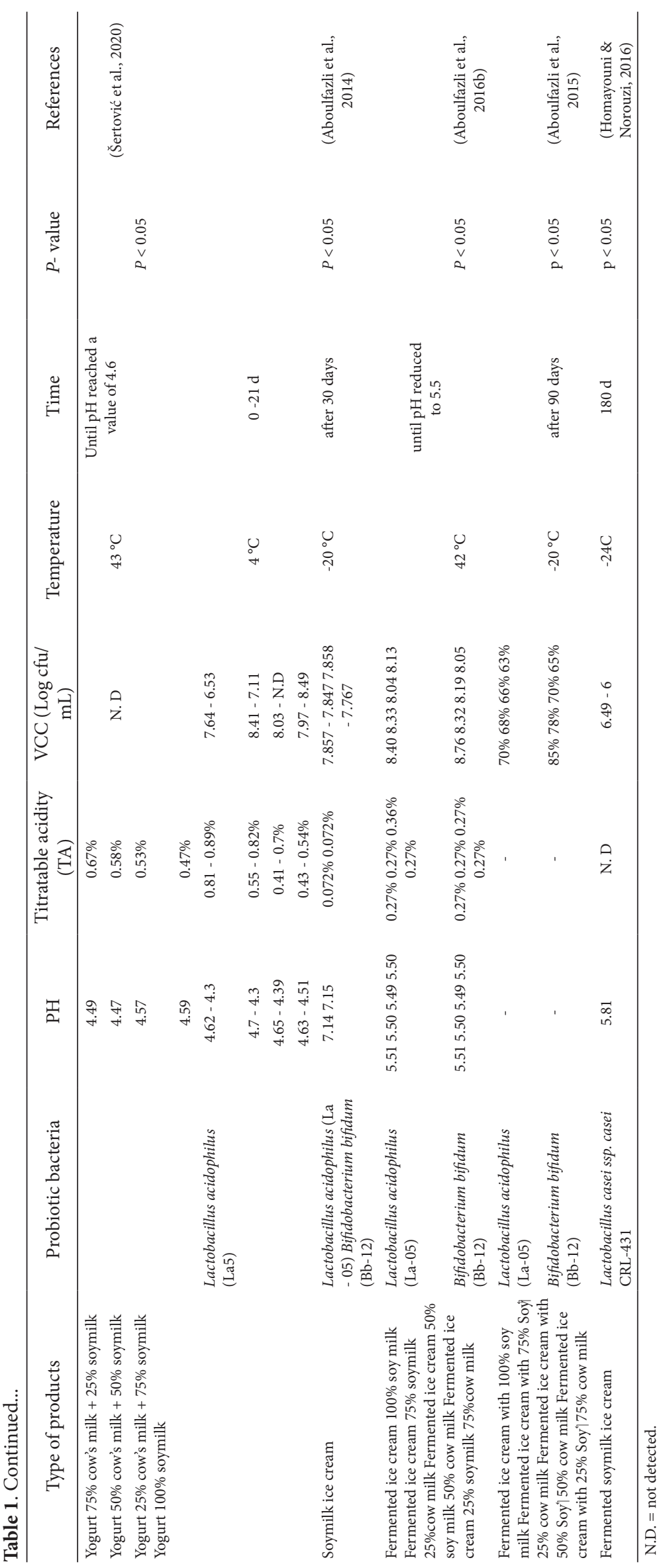


products are likely to be related to an increase in TA and a drop in $\mathrm{pH}$. This is attributed to the production of acids (mainly lactic acid) and organic acids during fermentation (Kumari et al., 2018; Šertović et al., 2020). In addition, post-acidification phenomena can be illustrated according to each microorganism's metabolic behavior (Mishra \& Mishra, 2013).

\subsection{Coconut milk}

The development of new non-dairy products from fermented coconut milk by probiotic bacteria was well studied (Yuliana \& Rangga, 2010; Amirah et al., 2020). Several studies have indicated that the fermentation process and time, temperature, and type of probiotic could be the main factors that affected the viability of probiotics in coconut milk during fermentation and storage (Mauro \& Garcia, 2019; Amirah et al., 2020). The incorporation of probiotics in coconut milk as a food matrix and their growth and viability during fermentation and storage is shown in Table 2. Aboulfazli et al. $(2015,2016 \mathrm{a})$ demonstrated that coconut milk ice cream can be a good carrier for Bifidobacterium bifidum (Bb-12) and L. acidophilus (La-05) during storage at $-20^{\circ} \mathrm{C}$ for up to 90 days of storage with viability ranged between 7-8 log $\mathrm{cfu} / \mathrm{g}$. However, the viable cell counts of B. bifidum in coconut

Table 2. Viable cell counts (VCC) of probiotics in coconut milk during fermentation and refrigerated storage.

\begin{tabular}{|c|c|c|c|c|c|c|c|c|}
\hline Type of products & Probiotic bacteria & $\mathrm{PH}$ & $\begin{array}{c}\text { Titratable } \\
\text { acidity (TA) }\end{array}$ & $\begin{array}{l}\text { VCC (Log } \\
\mathrm{cfu} / \mathrm{mL})\end{array}$ & Temperature & Time & $P$-value & References \\
\hline $\begin{array}{l}\text { Coconut milk yogurt } \\
\text { (CY) with raisin puree }\end{array}$ & Mixed culture & 4.33 & & 6.04 & & & & \\
\hline CY $0 \%$ & $\begin{array}{l}\text { Lactobacillus acidophilus } \\
\text { Lactobacillus salivarius } \\
\text { Bifidobacterium bifidum } \\
\text { and Streptococcus } \\
\text { thermophiles }\end{array}$ & & N. D & 6.11 & & & & \\
\hline CY17\% & & 4.24 & & 6.23 & $4^{\circ} \mathrm{C}$ & $15 \mathrm{~h}$ & $\mathrm{P}<0.05$ & (Amirah et al., 2020) \\
\hline CY $23 \%$ & & & & 6.38 & & & & \\
\hline \multirow[t]{2}{*}{ CY 29\% } & & 4.19 & & & & & & \\
\hline & & 4.20 & & & & & & \\
\hline \multirow{2}{*}{$\begin{array}{l}\text { Fermented coconut milk } \\
\text { drink }\end{array}$} & Lactobacillus acidophilus & $6.1-4$ & $0.1-0.6 \%$ & $4.32-9.89$ & $37^{\circ} \mathrm{C}$ & $0-20 \mathrm{~h}$ & $\mathrm{P}<0.05$ & \\
\hline & & $\begin{array}{c}3.79- \\
3.58\end{array}$ & $0.524-0.742 \%$ & $8.347-10.201$ & $5^{\circ} \mathrm{C}$ & $0-16 d$ & & $\begin{array}{l}\text { (Yuliana and Rangga, } \\
\text { 2010) }\end{array}$ \\
\hline \multirow[t]{2}{*}{ Coconut milk } & $\begin{array}{l}\text { Lactobacillus casei subsp. } \\
\text { rhamnosus }\end{array}$ & $\begin{array}{c}6.12- \\
5.66\end{array}$ & & $11.72-13.26$ & $37^{\circ} \mathrm{C}$ & $6 \mathrm{~h}$ & $\mathrm{p} \leq 0.05$ & \\
\hline & & $\begin{array}{c}5.61- \\
4.81\end{array}$ & N. D & $13.26-9.41$ & $4^{\circ} \mathrm{C}$ & $1-21 d$ & $\mathrm{p}<0.05$ & $\begin{array}{l}\text { (Szparaga et al., } \\
2019)\end{array}$ \\
\hline $\begin{array}{l}\text { Cow milk }+10 \%-50 \% \\
\text { coconut milk }\end{array}$ & & $4.1-3.8$ & $0.9-1 \%$ & $9.07-9.30$ & $30^{\circ} \mathrm{C}$ & $14 \mathrm{~h}$ & & \\
\hline 100\% Coconut milk & $\begin{array}{l}\text { Lactococcus lactis MTCC } \\
3041\end{array}$ & 4.6 & $1.1 \%$ & 9.20 & & & $\mathrm{p}<0.05$ & \\
\hline $\begin{array}{l}\text { Coconut milk with cow } \\
\text { milk supplemented }\end{array}$ & $\begin{array}{l}\text { Lactobacillus lactis MTCC } \\
3041 \text { and Lactobacillus }\end{array}$ & $6.2-4.8$ & $0.9-1.2 \%$ & $10-9.11$ & & & & (Sridhar et al., 2015) \\
\hline \multirow[t]{3}{*}{ Dahi (curd) } & plantarum MTCC 5422 & & & & $37^{\circ} \mathrm{C}$ & $0-16 h$ & $\mathrm{p}<0.05$ & \\
\hline & $\begin{array}{l}\text { Lactobacillus lactis MTCC } \\
3041 \text { and Leuconostoc sp. } \\
\text { MTCC } 10508\end{array}$ & $6.3-4.6$ & $0.5-1.3 \%$ & $10-9.61$ & & & & \\
\hline & & $\begin{array}{c}6.36- \\
4.28\end{array}$ & $\begin{array}{c}0.14-0.33 \mathrm{~g} / 100 \\
\mathrm{~mL}\end{array}$ & $6.21-8.2$ & $37^{\circ} \mathrm{C}$ & $0-48 \mathrm{~h}$ & $\mathrm{p}<0.05$ & \\
\hline \multirow[t]{4}{*}{ Coconut milk beverage } & Lactobacillus reuteri LR 92 & $\begin{array}{c}6.45- \\
3.32\end{array}$ & $\begin{array}{c}0.15-0.32 \mathrm{~g} / 100 \\
\mathrm{~mL}\end{array}$ & $6.24-9.3$ & $34^{\circ} \mathrm{C}$ & & & $\begin{array}{l}\text { (Mauro \& Garcia, } \\
\text { 2019) }\end{array}$ \\
\hline & $\begin{array}{l}\text { Lactobacillus reuteri DSM } \\
17938\end{array}$ & $\begin{array}{c}4.59- \\
4.33\end{array}$ & $\begin{array}{c}0.13-0.16 \mathrm{~g} / 100 \\
\mathrm{~mL}\end{array}$ & $8.04-7.55$ & $4^{\circ} \mathrm{C}$ & $0-30 d$ & & \\
\hline & & $\begin{array}{c}4.53- \\
3.60\end{array}$ & $\begin{array}{c}0.15-0.46 \mathrm{~g} / 100 \\
\mathrm{~mL}\end{array}$ & $8.64-8.57$ & & & & \\
\hline & & 5.50 & $0.27 \%$ & $8.07-7.3$ & & & & \\
\hline \multirow[t]{2}{*}{ Frozen fermented dessert } & Lactobacillus acidophilus & 5.50 & $0.27 \%$ & $7.61-6.74$ & & & & \\
\hline & & 5.51 & $0.27 \%$ & $8.02-6.32$ & $-20^{\circ} \mathrm{C}$ & after 90 days & $\mathrm{P}<0.05$ & $\begin{array}{l}\text { (Aboulfazli et al., } \\
\text { 2016a) }\end{array}$ \\
\hline $100 \%$ coconut milk & & 5.50 & $0.27 \%$ & $8.42-6.87$ & & & & \\
\hline \multicolumn{9}{|l|}{$\begin{array}{l}75 \% \text { Soymilk }+25 \% \\
\text { Coconut milk }\end{array}$} \\
\hline \multicolumn{9}{|l|}{$\begin{array}{l}50 \% \text { Soymilk }+50 \% \\
\text { Coconut milk }\end{array}$} \\
\hline $\begin{array}{l}25 \% \text { Soymilk + } 75 \% \\
\text { Coconut milk }\end{array}$ & & 5.50 & $0.27 \%$ & $8.42-7.91$ & & & & \\
\hline
\end{tabular}

N.D. $=$ not detected. 
Table 2. Continued...

\begin{tabular}{|c|c|c|c|c|c|c|c|c|}
\hline Type of products & Probiotic bacteria & $\mathrm{PH}$ & $\begin{array}{c}\text { Titratable } \\
\text { acidity (TA) }\end{array}$ & $\begin{array}{c}\text { VCC (Log } \\
\mathrm{cfu} / \mathrm{mL})\end{array}$ & Temperature & Time & $P$-value & References \\
\hline & & 5.52 & $0.27 \%$ & $8.51-7.82$ & & & & \\
\hline & $\begin{array}{l}\text { Bifidobacterium bifidum } \\
\text { (Bb-12) }\end{array}$ & 5.50 & $0.27 \%$ & $8.56-7.94$ & & & & \\
\hline & & 5.51 & $0.27 \%$ & $8.59-8.04$ & & & & \\
\hline $\begin{array}{l}\text { Fermented ice cream } \\
\text { with } 100 \% \text { coconut milk }\end{array}$ & $\begin{array}{l}\text { Lactobacillus acidophilus } \\
\text { (La-05) }\end{array}$ & 5.50 & $0.27 \%$ & 8.30 & & & & \\
\hline $\begin{array}{l}\text { Fermented ice cream } \\
\text { with } 75 \% \text { soy milk } \text { and } \\
25 \% \text { coconut milk }\end{array}$ & & 5.50 & $0.27 \%$ & 8.76 & & & & \\
\hline $\begin{array}{l}\text { Fermented ice cream } \\
\text { with } 50 \% \text { soymilk and } \\
50 \% \text { coconut milk }\end{array}$ & & 5.51 & $0.27 \%$ & 8.18 & & & & \\
\hline \multirow{5}{*}{$\begin{array}{l}\text { Fermented ice cream } \\
\text { with } 25 \% \text { soy milk and } \\
75 \% \text { coconut milk }\end{array}$} & & 5.5 & $0.27 \%$ & 7.73 & $42^{\circ} \mathrm{C}$ & $\begin{array}{c}\text { until pH } \\
\text { reduced to } 5.5\end{array}$ & $\mathrm{p}<0.05$ & \\
\hline & Bifidobacterium bifidum & 5.50 & $0.27 \%$ & 8.70 & & & & \\
\hline & $(\mathrm{Bb}-12)$ & 5.52 & $0.27 \%$ & 8.57 & & & & \\
\hline & & 5.50 & $0.27 \%$ & 8.57 & & & & \\
\hline & & 5.51 & $0.27 \%$ & 8.59 & & & & \\
\hline $\begin{array}{l}\text { Fermented ice cream } \\
\text { with } 100 \% \text { coconut milk }\end{array}$ & $\begin{array}{l}\text { Lactobacillus acidophilus } \\
\text { (La-05) }\end{array}$ & N. D & N. D & $64 \%$ & & & & \\
\hline $\begin{array}{l}\text { Fermented ice cream } \\
\text { with } 75 \% \text { soy milk } \bigotimes \text { and } \\
25 \% \text { coconut milk }\end{array}$ & & & & $69 \%$ & & & & \\
\hline $\begin{array}{l}\text { Fermented ice cream } \\
\text { with } 50 \% \text { soymilk and } \\
50 \% \text { coconut milk }\end{array}$ & & & & $67 \%$ & & & & \\
\hline \multirow{5}{*}{$\begin{array}{l}\text { Fermented ice cream } \\
\text { with } 25 \% \text { soy milk and } \\
75 \% \text { coconut milk }\end{array}$} & & & & $64 \%$ & $-20^{\circ} \mathrm{C}$ & after 90 days & $\mathrm{p}<0.05$ & $\begin{array}{l}\text { (Aboulfazli et al., } \\
\text { 2015) }\end{array}$ \\
\hline & Bifidobacterium bifidum & N. D & N. D & $86 \%$ & & & & \\
\hline & $(\mathrm{Bb}-12)$ & & & $89 \%$ & & & & \\
\hline & & & & $82 \%$ & & & & \\
\hline & & & & $81 \%$ & & & & \\
\hline \multirow[t]{2}{*}{ Coconut milk ice cream } & $\begin{array}{l}\text { Lactobacillus acidophilus } \\
\text { (La - 05) }\end{array}$ & 6.71 & $0.117 \%$ & $7.121-6.870$ & & & & \\
\hline & $\begin{array}{l}\text { Bifidobacterium bifidum } \\
(\mathrm{Bb}-12)\end{array}$ & 6.72 & $0.126 \%$ & $7.745-7.371$ & $-20^{\circ} \mathrm{C}$ & after 30 days & $\mathrm{p}<0.05$ & $\begin{array}{l}\text { (Aboulfazli et al., } \\
\text { 2014) }\end{array}$ \\
\hline
\end{tabular}

N.D. = not detected.

milk ice cream were significantly higher $(86 \%$; $p<0.05)$ than L. acidophilus $(64 \%)$ after 3 months of storage at $-20^{\circ} \mathrm{C}$. This indicated that the viability of probiotics in coconut milk ice cream is strongly influenced by the strain used. Yuliana \& Rangga (2010) have studied the coconut milk fermented with L. bulgaricus, $S$. thermophilus, and L. acidophilus. The authors found that the growth of L. acidophilus in coconut milk was increased $(\mathrm{p}<0.05)$ from 4.32 to $9.89 \log \mathrm{cfu} / \mathrm{mL}$ after 20 hours of fermentation at $37^{\circ} \mathrm{C}$. In addition, the viability of $L$. acidophilus was remained constant during two weeks of refrigerated storage at $5{ }^{\circ} \mathrm{C}$. Similarly, L. rhamnosus and L. reuteri showed a significant growth and survival rate in fermented coconut milk during fermentation and storage (Table 2). Furthermore, the growth and viability of probiotics strains in fermented coconut milk might be enhanced with the food additives such as raisin puree and fermented milk "Dahi" (Sridhar et al., 2015; Amirah et al., 2020).

\subsection{Other plant-based milk}

Several researchers have studied the growth and viability of probiotics in fermented plant-based milk products during fermentation and storage (Table 3). Previous studies have confirmed that almond- and cashew- milk were an excellent carrier for probiotics (Bernat et al., 2015; Wansutha et al., 2018; Bruno et al., 2019). Kabier et al., (2014) have investigated the growth of $B$. pseudoatenulatum $\mathrm{G} 4$ in peanut milk during fermentation at 37 ${ }^{\circ} \mathrm{C}$. They found that $B$. pseudoatenulatum $\mathrm{G} 4$ increased from 4.74 to $7.12 \log \mathrm{cfu} / \mathrm{mL}$ after 24 hours of fermentation. In addition, fructooligosaccharides supplementation enhanced the growth of $B$. pseudoatenulatum $\mathrm{G} 4$ in peanut milk during fermentation. On the other hand, B. longum BB536 showed a significant reduction $(\sim 2 \log \mathrm{cfu} / \mathrm{mL} ; \mathrm{p}<0.05)$ in fermented peanut milk after a week of refrigerated storage at $4{ }^{\circ} \mathrm{C}($ Table 3$)$. Fermented 
Table 3. Viable cell counts (VCC) of probiotics in other plant-based milk during fermentation and refrigerated storage.

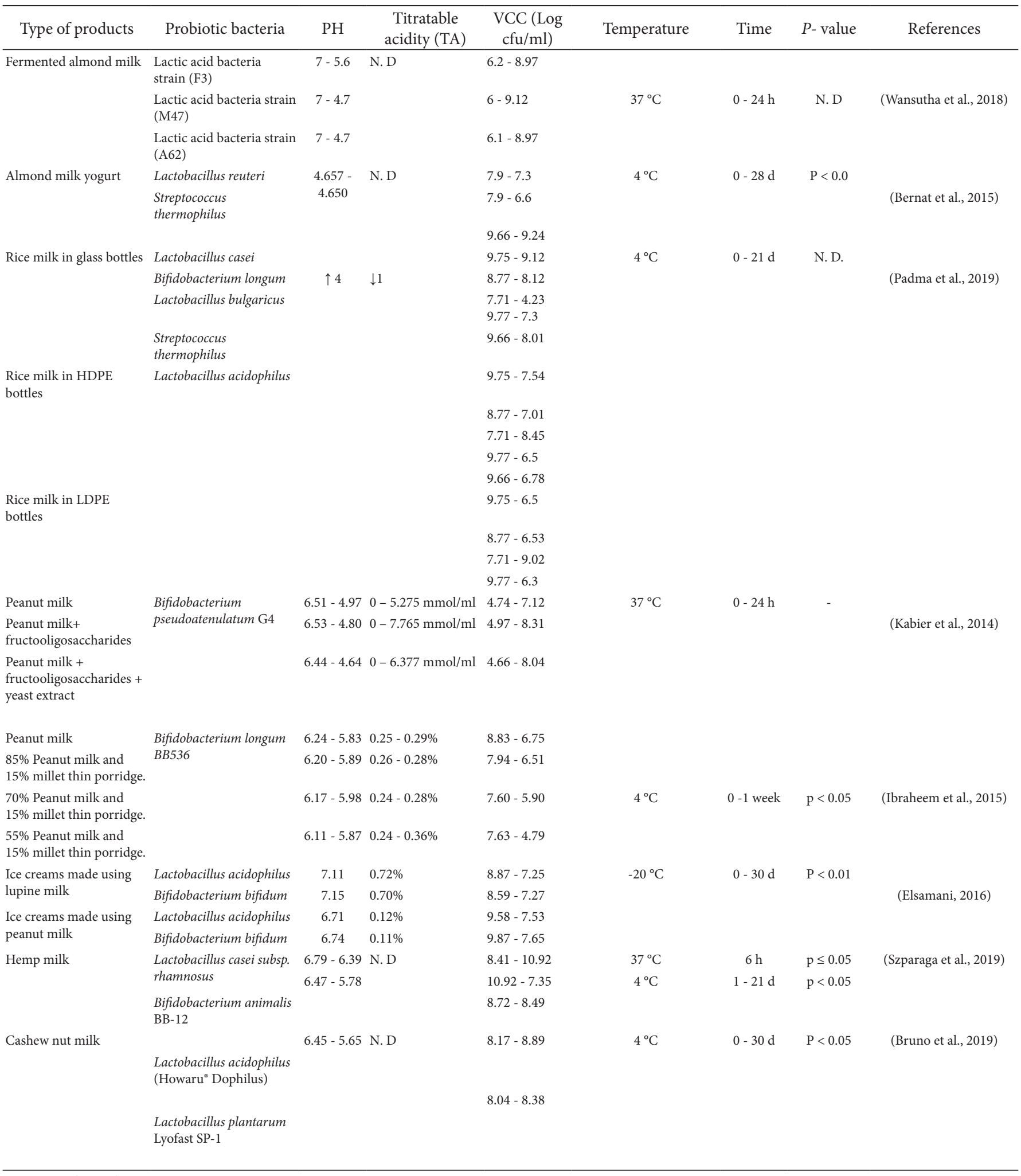

rice milk prepared from broken rice was found to be suitable substrates to support high cell viability of probiotic strains such as L. casei, B. longum, L. bulgaricus, S. thermophilus, and L. acidophilus during 21 days of refrigerated storage (Padma et al.,
2019; Table 3). In addition, glass bottles were the best packaging material for fermented rice milk to maintained high viable cells count of probiotics (Padma et al., 2019). A recent study revealed that the viability of L. rhamnosus in hemp milk was significantly 
( $\mathrm{p}<0.05)$ increased from 8 to $11 \log \mathrm{CFU} / \mathrm{mL}$ during 6 hours of fermentation. However, this value was reduced to $7.35 \mathrm{log}$ $\mathrm{CFU} / \mathrm{mL}$ after 21 days of storage at $4{ }^{\circ} \mathrm{C}$ (Szparaga et al., 2019).

\section{Conclusion}

In the last few years, there is an increase in the need to develop dairy substitutes for the sake of physical health. Based on evidence-based reviews of research findings on the fermentation of plant-based milk alternatives, it can be concluded that plantbased milk could be a good alternative as a probiotics carrier. Therefore, further studies are required for plant-based dairy products to improve the fermentation process, nutritional values, growth, and viability of probiotics, extend the shelf life of the final product, and improve the functional properties.

\section{References}

Abou-Dobara, M., Ismail, M., \& Refaat, N. (2016). Chemical composition, sensory evaluation and starter activity in cow, soy, peanut and rice milk. Journal of Nutritional Health \& Food Engineering, 5(3), 00175.

Aboulfazli, F., Baba, A. S., \& Misran, M. (2015). The rheology and physical properties of fermented probiotic ice creams made with dairy alternatives. International Journal of Food Engineering, 11(4), 493-504. http://dx.doi.org/10.1515/ijfe-2014-0343.

Aboulfazli, F., Baba, A. S., \& Misran, M. (2016a). Replacement of bovine milk with vegetable milk: effects on the survival of probiotics and rheological and physicochemical properties of frozen fermented dessert. International Journal of Dairy Technology, 69(1), 71-80. http://dx.doi.org/10.1111/1471-0307.12219.

Aboulfazli, F., Baba, A., \& Misran, M. (2014). Effects of vegetable milk on survival of probiotics and rheological and physicochemical properties of bio-ice cream. In International Conference on Biological and Medical Sciences (15-16). Bali: ICBMS.

Aboulfazli, F., Shori, A. B., \& Baba, A. S. (2016b). Effects of the replacement of cow milk with vegetable milk on probiotics and nutritional profile of fermented ice cream. LWT, 70, 261-270. http:// dx.doi.org/10.1016/j.lwt.2016.02.056.

Afolabi, I. S., Nwachukwu, I. C., Ezeoke, C. S., Woke, R. C., Adegbite, O. A., Olawole, T. D., \& Martins, O. C. (2018). Production of a new Plant-Based Milk from Adenanthera pavonina seed and evaluation of its nutritional and health benefits. Frontiers in Nutrition, 5, 9. http://dx.doi.org/10.3389/fnut.2018.00009. PMid:29556498.

Al-Saedi, N., Agarwal, M., Ma, W., Islam, S., \& Ren, Y. (2020). Proteomic characterisation of lupin (Lupinus angustifolius) milk as influenced by extraction techniques, seed coat and cultivars. Molecules, 25(8), 1782. http://dx.doi.org/10.3390/molecules25081782. PMid:32295067.

Aluko, R. (2017). Hemp seed (Cannabis sativa L.) proteins: composition, structure, enzymatic modification, and functional or bioactive properties. In S. R. Nadathur, J. P. D. Wanasundara \& L. Scanlin (Eds.), Sustainable protein sources (pp. 121-132). Amsterdam: Elsevier.

Amirah, A., Syazwani, S., Radhiah, S., Shobirin, M., Nor-Khaizura, M. A. R., Zunairah, W. I. W., \& Shazini, R. N. (2020). Influence of raisins puree on the physicochemical properties, resistant starch, probiotic viability and sensory attributes of coconut milk yogurt. Food Research, 4(1), 77-84.

Arya, S. S., Salve, A. R., \& Chauhan, S. (2016). Peanuts as functional food: a review. Journal of Food Science and Technology, 53(1), 3141. http://dx.doi.org/10.1007/s13197-015-2007-9. PMid:26787930.
Balthazar, C. F., Moura, N. A., Romualdo, G. R., Rocha, R. S., Pimentel, T. C., Esmerino, E. A., Freitas, M. Q., Santillo, A., Silva, M. C., Barbisan, L. F., Cruz, A. G., \& Albenzio, M. (2021). Synbiotic sheep milk ice cream reduces chemically induced mouse colon carcinogenesis. Journal of Dairy Science, 104(7), 7406-7414. http:// dx.doi.org/10.3168/jds.2020-19979. PMid:33934866.

Bansal, S., Mangal, M., Sharma, S. K., Yadav, D. N., \& Gupta, R. K. (2016). Optimization of process conditions for developing yoghurt like probiotic product from peanut. $L W T, 73,6-12$. http://dx.doi. org/10.1016/j.lwt.2016.04.059.

Barreira, J. C., Ferreira, I. C., Oliveira, M. B. P., \& Pereira, J. A. (2008). Antioxidant activity and bioactive compounds of ten Portuguese regional and commercial almond cultivars. Food and Chemical Toxicology, 46(6), 2230-2235. http://dx.doi.org/10.1016/j.fct.2008.02.024. PMid:18400354.

Bernat, N., Cháfer, M., Chiralt, A., \& González-Martínez, C. (2014). Vegetable milks and their fermented derivative products. International Journal of Food Studies, 3(1), 93-124. http://dx.doi.org/10.7455/ ijfs/3.1.2014.a9.

Bernat, N., Cháfer, M., Chiralt, A., \& González-Martínez, C. (2015). Probiotic fermented almond "milk" as an alternative to cow-milk yoghurt. International Journal of Food Studies, 4(2), 201-211. http:// dx.doi.org/10.7455/ijfs/4.2.2015.a8.

Bridges, M. (2018). Moo-ove Over, Cow's Milk: The Rise of Plant-Based Dairy Alternatives. Nutrition Issues in Gastroenterology, 171, 20-27.

Bruno, L. M., Lima, J. R., Wurlitzer, N. J., \& Rodrigues, T. C. (2019). Non-dairy cashew nut milk as a matrix to deliver probiotic bacteria. Food Science and Technology, 40(3), 604-607. http://dx.doi. org/10.1590/fst.14219.

Chinsembu, K., Cheikhyoussef, A., Mumbengegwi, D., Kandawa-Schulz, M., Kasanda, C., \& Kazembe, L. (2015). Indigenous knowledge of Namibia. Windhoek: University of Namibia.

Clay, N., Sexton, A. E., Garnett, T., \& Lorimer, J. (2020). Palatable disruption: the politics of plant milk. Agriculture and Human Values, 37(4), 945-962. http://dx.doi.org/10.1007/s10460-020-10022-y. PMid:33184529.

Costa, G. M., Paula, M. M., Costa, G. N., Esmerino, E. A., Silva, R., Freitas, M. Q., Barao, C. E., Cruz, A. G., \& Pimentel, T. C. (2020). Preferred attribute elicitation methodology compared to conventional descriptive analysis: a study using probiotic yogurt sweetened with xylitol and added with prebiotic components. Journal of Sensory Studies, 35(6), e12602. http://dx.doi.org/10.1111/joss.12602.

Curl, S., Rivero-Mendoza, D. \& Dahl, W. J. (2020). Plant-based milks: hemp. Food Science and Human Nutrition, 2020(5), 20-53.

D’Amato, A., Fasoli, E., \& Righetti, P. G. (2012). Harry Belafonte and the secret proteome of coconut milk. Journal of Proteomics, 75(3), 914920. http://dx.doi.org/10.1016/j.jprot.2011.10.009. PMid:22037231.

Daramola, J. O., Adekunle, E. O., Iyasere, O. S., Oke, O. E., Sorongbe, T. A., Iyanda, O. A., Kehinde, A. R., Aluko, S. P., Olaoye, I. O., Gbadebo, O. E., Falolu, L. I., Olukayode, E. O., Ajayi, R. A., Enikannaye, O. J., \& Osunjaiye, E. D. (2016). Effects of coconut milk alone or supplementation with pyridoxine in tris-extenders on viability of buck spermatozoa during vitrification. Small Ruminant Research, 136, 208-213. http://dx.doi.org/10.1016/j.smallrumres.2016.02.004.

Ebhodaghe, S., Abiose, S., \& Adeniran, H. (2012). Assessment of physico-chemical characteristics, viability and inhibitory effect of Bifidobacteria in soymilk. Journal of Food Research, 1(2), 159-170. http://dx.doi.org/10.5539/jfr.v1n2p159.

Elsamani, M. O. (2016). Probiotics, organoleptic and physicochemical properties of vegetable milk based bio-ice cream supplemented with 
skimmed milk powder. International Journal of Nutrition and Food Sciences, 5(5), 361-366. http://dx.doi.org/10.11648/j.ijnfs.20160505.17.

Elsamani, M. O., Habbani, S. S., Babiker, E. E., \& Ahmed, I. A. M. (2014). Biochemical, microbial and sensory evaluation of white soft cheese made from cow and lupin milk. Lebensmittel-Wissenschaft + Technologie, 59(1), 553-559. http://dx.doi.org/10.1016/j.lwt.2014.04.027.

Eor, J. Y., Tan, P. L., Son, Y. J., Lee, C. S., \& Kim, S. H. (2020). Milk products fermented by Lactobacillus strains modulate the gut-bone axis in an ovariectomised murine model. International Journal of Dairy Technology, 73(4), 743-756. http://dx.doi.org/10.1111/14710307.12708 .

Farnworth, E. R., Mainville, I., Desjardins, M.-P., Gardner, N., Fliss, I., \& Champagne, C. (2007). Growth of probiotic bacteria and bifidobacteria in a soy yogurt formulation. International Journal of Food Microbiology, 116(1), 174-181. http://dx.doi.org/10.1016/j. ijfoodmicro.2006.12.015 PMid:17292991.

Good Food Institute - GFI. (2019). Plant-based food retail sales are growing $5 x$ total food sales. Retrieved from https://www.gfi.org/ spins-data-release-2019.

Grom, L. C., Rocha, R. S., Balthazar, C. F., Guimarães, J. T., Coutinho, N. M., Barros, C. P., Pimentel, T. C., Venâncio, E. L., Collopy, I. C. Jr., Maciel, P. M. C., Silva, P. H. F., Granato, D., Freitas, M. Q., Esmerino, E. A., Silva, M. C. \& Cruz, A. G. (2020). Postprandial glycemia in healthy subjects: which probiotic dairy food is more adequate? Journal of Dairy Science, 103(2), 1110-1119. http://dx.doi. org/10.3168/jds.2019-17401 PMid:31785881.

Hadjimbei, E., Botsaris, G., Goulas, V., Alexandri, E., Gekas, V., \& Gerothanassis, I. P. (2020). Functional stability of goats' milk yoghurt supplemented with Pistacia atlantica resin extracts and Saccharomyces boulardii. International Journal of Dairy Technology, 73(1), 134-143. http://dx.doi.org/10.1111/1471-0307.12629.

Hati, S., Patel, N., \& Mandal, S. (2018). Comparative growth behaviour and biofunctionality of lactic acid bacteria during fermentation of soy milk and bovine milk. Probiotics and Antimicrobial Proteins, 10(2), 277-283. http://dx.doi.org/10.1007/s12602-017-9279-5 PMid:28455690.

Hill, C., Guarner, F., Reid, G., Gibson, G. R., Merenstein, D. J., Pot, B., Morelli, L., Canani, R. B., Flint, H. J., Salminen, S., Calder, P. C., \& Sanders, M. E. (2014). Expert consensus document: The International Scientific Association for Probiotics and Prebiotics consensus statement on the scope and appropriate use of the term probiotic. Nature Reviews: Gastroenterology \& Hepatology, 11(8), 506-514. http://dx.doi.org/10.1038/nrgastro.2014.66 PMid:24912386.

Homayouni, A., \& Norouzi, S. (2016). Evaluation of physicochemical traits, sensory properties and survival of lactobacillus casei in fermented soy-based ice cream. Journal of Food Processing and Preservation, 40(4), 681-687. http://dx.doi.org/10.1111/jfpp.12648.

Horáčková, Š., Mühlhansová, A., Sluková, M., Schulzová, V., \& Plocková, M. (2015). Fermentation of soymilk by yoghurt and bifidobacteria strains. Czech Journal of Food Sciences, 33(4), 313-319. http://dx.doi. org/10.17221/115/2015-CJFS.

Ibraheem, S. E., Kabeir, B. M., \& Mohammed, L. H. (2015). Survival of Bifidobacterium longum BB536 and physicochemical changes during refrigeration storage of fermented roasted peanuts milk partially substituted with millet thin porridge. International Journal of Current Microbiology and Applied Sciences, 4(9), 380-389.

Ismaiel, M., El-Wahed, A., Khalifa, S., Baky, A., \& Ashor, M. (2018). Growth and survival of probiotic bacteria in fermented flavoured soy milk drinks during storage. Zagazig Journal of Agricultural Research, 45(1), 281-292. http://dx.doi.org/10.21608/zjar.2018.49850.
Jayachandran, M., \& Xu, B. (2019). An insight into the health benefits of fermented soy products. Food Chemistry, 271, 362-371. http:// dx.doi.org/10.1016/j.foodchem.2018.07.158. PMid:30236688.

Jeske, S., Zannini, E., \& Arendt, E. K. (2018). Past, present and future: the strength of plant-based dairy substitutes based on gluten-free raw materials. Food Research International, 110, 42-51. http://dx.doi. org/10.1016/j.foodres.2017.03.045. PMid:30029705.

Jiménez-Martínez, C., Hernández-Sánchez, H., \& Dávila-Ortiz, G. (2003). Production of a yogurt-like product from Lupinus campestris seeds. Journal of the Science of Food and Agriculture, 83(6), 515-522. http://dx.doi.org/10.1002/jsfa.1385.

Joel, N., Samaila, J., \& Blessing, O. (2019). Development and comparative evaluation of storage changes in probiotic soy-yoghurt. Journal of Microbiology, Biotechnology and Food Sciences, 9(2), 298-301. http:// dx.doi.org/10.15414/jmbfs.2019.9.2.298-301.

Kabier, B. M., Yazid, A. M., \& Mustafa, S. (2014). Growth of Bifidobacterium pseudocatenulatum $\mathrm{G} 4$ and changes in organic acid profile in peanut milk and skim milk supplemented with fructooligosaccharides. Sudan Journal of Science and Technology, 15(2), 12-21.

Kadam, S., \& Salunkhe, D. (1989). Handbook of world food legumes: nutritional chemistry, processing technology, and utilization. Boca Raton: CRC.

Katz, A. C. (2018). Milk nutrition and perceptions (Honors Thesis). Johnson \& Wales University, Providence.

Ketnawa, S., \& Ogawa, Y. (2019). Evaluation of protein digestibility of fermented soybeans and changes in biochemical characteristics of digested fractions. Journal of Functional Foods, 52, 640-647. http:// dx.doi.org/10.1016/j.jff.2018.11.046.

Khan, M. K., Karnpanit, W., Nasar-Abbas, S. M., Huma, Z. E., \& Jayasena, V. (2015). Phytochemical composition and bioactivities of lupin: a review. International Journal of Food Science \& Technology, 50(9), 2004-2012. http://dx.doi.org/10.1111/ijfs.12796.

Kumari, A., Angmo, K., Monika, S., \& Bhalla, T. (2018). Functional and technological application of probiotic L. casei PLA5 in fermented soymilk. International Food Research Journal, 25(5), 2164-2172.

Lee, C. S., Lee, S. H., \& Kim, S. H. (2020). Bone-protective effects of Lactobacillus plantarum B719-fermented milk product. International Journal of Dairy Technology, 73(4), 706-717. http:// dx.doi.org/10.1111/1471-0307.12701.

Levit, R., Giori, G. S., LeBlanc, A. M., \& LeBlanc, J. G. (2017). Evaluation of the effect of soymilk fermented by a riboflavin-producing Lactobacillus plantarum strain in a murine model of colitis. Beneficial Microbes, 8(1), 65-72. http://dx.doi.org/10.3920/BM2016.0063. PMid:27873546.

Lim, X., Koh, W., Uthumporn, U., Maizura, M. \& Rosli, W. I. W. (2019). The development of legume-based yogurt by using water kefir as starter culture. International Food Research Journal, 26(4), 1219-1228.

Liong, M. T., \& Shah, N. (2006). Effects of a Lactobacillus casei synbiotic on serum lipoprotein, intestinal microflora, and organic acids in rats. Journal of Dairy Science, 89(5), 1390-1399. http://dx.doi.org/10.3168/ jds.S0022-0302(06)72207-X. PMid:16606710.

Liu, J. R., \& Lin, C. W. (2000). Production of kefir from soymilk with or without added glucose, lactose, or sucrose. Journal of Food Science, 65(4), 716-719. http://dx.doi.org/10.1111/j.1365-2621.2000.tb16078.x.

Lucatto, J. N., Silva-Buzanello, R. A., Mendonça, S. N. T. G., Lazarotto, T. C., Sanchez, J. L., Bona, E., \& Drunkler, D. A. (2020). Performance of different microbial cultures in potentially probiotic and prebiotic yoghurts from cow and goat milks. International Journal of Dairy Technology, 73(1), 144-156. http://dx.doi.org/10.1111/1471-0307.12655.

Mäkinen, O. E., Wanhalinna, V., Zannini, E., \& Arendt, E. K. (2016). Foods for special dietary needs: non-dairy plant-based milk substitutes 
and fermented dairy-type products. Critical Reviews in Food Science and Nutrition, 56(3), 339-349. http://dx.doi.org/10.1080/10408398 .2012.761950. PMid:25575046.

Manzoor, M. F. (2017). Effect of cooking temperature on some quality characteristic of Almond milk. International Journal of Agricultural and Life Sciences, 3(1), 131-135.

Manzoor, M. F., Manzoor, A., Siddique, R., \& Ahmad, N. (2017). Nutritional and sensory properties of cashew seed (Anacardium occidentale) milk. Modern Concepts \& Developments in Agronomy, $1(1), 1-4$.

Mauro, C. S. I., \& Garcia, S. (2019). Coconut milk beverage fermented by Lactobacillus reuteri: optimization process and stability during refrigerated storage. Journal of Food Science and Technology, 56(2), 854-864. http://dx.doi.org/10.1007/s13197-018-3545-8. PMid:30906043.

Mazumder, M. A. R., \& Begum, A. A. (2016). Soy milk as source of nutrient for malnourished population of developing country: a review. International Journal of Advanced Scientific and Technical Research, 5(6), 192-203.

Mintel Press Team. (2018). US non-dairy milk sales grow $61 \%$ over the last five years. Retrieved from https://www.mintel.com/press-centre/ food-and-drink/us-non-dairy-milk-sales-grow-61-over-the-lastfive-years.

Miraghajani, M., Zaghian, N., Dehkohneh, A., Mirlohi, M., \& Ghiasvand, R. (2019). Probiotic soymilk consumption and renal function among Type 2 diabetic patients with nephropathy: a randomized controlled clinical trial. Probiotics and Antimicrobial Proteins, 11(1), 124-132. http://dx.doi.org/10.1007/s12602-017-9325-3. PMid:28884306.

Mishra, B. K., Hati, S., Das, S., \& Prajapati, J. B. (2019). Biofunctional attributes and storage study of soy milk fermented by Lactobacillus rhamnosus and Lactobacillus helveticus. Food Technology and Biotechnology, 57(3), 399-407. http://dx.doi.org/10.17113/ ftb.57.03.19.6103. PMid:31866753.

Mishra, S., \& Mishra, H. (2013). Effect of synbiotic interaction of fructooligosaccharide and probiotics on the acidification profile, textural and rheological characteristics of fermented soy milk. Food and Bioprocess Technology, 6(11), 3166-3176. http://dx.doi. org/10.1007/s11947-012-1021-4.

Myagmardorj, B., Purev, M., \& Batdorj, B. (2018). Functional properties of fermented soymilk by Lactobacillus fermentum BM-325. Mongolian Journal of Chemistry, 19(45), 32-37. http://dx.doi.org/10.5564/mjc. v19i45.1087.

Nair, K. P. (2010). The agronomy and economy of important tree crops of the developing world. London: Elsevier.

National Institutes of Health. (2008). Vitamin and mineral supplement fact sheets. Bethesda: NIH Office of Dietary Supplements.Niamah, A. K., Sahi, A. A., \& Al-Sharifi, A. S. (2017). Chemical and microbial composition of fermented soy milk by probiotic starter. In $1^{\text {ST }}$ Scientific Conference of Agricultural Sciences. Iraq: Thi Qar University/ Sumer University.

Oliveira, L., Torres, D., \& Pinho, O. (2014). Lupin: nutritional composition and applications in the food industry. In IJUP - 7th Meeting of Young Researchers of University of Porto. Porto: University of Porto.

Oyeyinka, A. T., Odukoya, J. O., \& Adebayo, Y. S. (2019). Nutritional composition and consumer acceptability of cheese analog from soy and cashew nut milk. Journal of Food Processing and Preservation, 43(5), e14285. http://dx.doi.org/10.1111/jfpp.14285.

Padma, E. M., Rao, P. J., Edukondalu, L., Aparna, K., \& Babu, G. R. (2019). Storage studies of probiotic rice milk during refrigerated conditions. International Journal of Chemical Studies, 7(6), 1114-1117.
Panghal, A., Janghu, S., Virkar, K., Gat, Y., Kumar, V., \& Chhikara, N. (2018). Potential non-dairy probiotic products: a healthy approach. Food Bioscience, 21, 80-89. http://dx.doi.org/10.1016/j.fbio.2017.12.003.

Paul, A. A., Kumar, S., Kumar, V., \& Sharma, R. (2020). Milk analog: plant based alternatives to conventional milk, production, potential and health concerns. Critical Reviews in Food Science and Nutrition, 60(18), 3005-3023. http://dx.doi.org/10.1080/10408398.2019.1674 243. PMid:31617734.

Pena, F. L., Souza, M. C., Valle, M. C. P., Bezerra, R. M., Rostagno, M. A., \& Antunes, A. E. (2021). Probiotic fermented milk with high content of polyphenols: study of viability and bioaccessibility after simulated digestion. International Journal of Dairy Technology, 74(1), 170-180. http://dx.doi.org/10.1111/1471-0307.12735.

Rasika, D. M., Vidanarachchi, J. K., Rocha, R. S., Balthazar, C. F., Cruz, A. G., Sant'Ana, A. S., \& Ranadheera, C. S. (2020). Plant-based milk substitutes as emerging probiotic carriers. Current Opinion in Food Science, 38, 8-20. http://dx.doi.org/10.1016/j.cofs.2020.10.025.

Ryan, J., Hutchings, S. C., Fang, Z., Bandara, N., Gamlath, S., Ajlouni, S., \& Ranadheera, C. S. (2020). Microbial, physico-chemical and sensory characteristics of mango juice-enriched probiotic dairy drinks. International Journal of Dairy Technology, 73(1), 182-190. http://dx.doi.org/10.1111/1471-0307.12630.

Sadeghi, O., Milajerdi, A., Siadat, S. D., Keshavarz, S. A., Sima, A. R., Vahedi, H., Adibi, P., \& Esmaillzadeh, A. (2020). Effects of soy milk consumption on gut microbiota, inflammatory markers, and disease severity in patients with ulcerative colitis: a study protocol for a randomized clinical trial. Trials, 21(1), 565. http://dx.doi. org/10.1186/s13063-020-04523-8. PMid:32576228.

Šertović, E., Sarić, Z., Božanić, R., Barać, M., Barukčić, I., \& Kostić, A. (2020). Fermentation of cow's milk and soy milk mixture with L. acidophilus probiotic bacteria with yoghurt culture. ScientificExperts Conference of Agriculture and Food Industry, 78, 251-259. http://dx.doi.org/10.1007/978-3-030-40049-1_32.

Shori, A. B. (2013b). Antioxidant activity and viability of lactic acid bacteria in soybean-yogurt made from cow and camel milk. Journal of Taibah University for Science, 7(4), 202-208. http://dx.doi. org/10.1016/j.jtusci.2013.06.003.

Shori, A. B. (2021). Application of Bifidobacterium spp in beverages and dairy food products: an overview of survival during refrigerated storage. Food Science and Technology. Ahead of print. http://dx.doi. org/10.1590/fst.41520.

Shori, A. B., Aboulfazli, F. \& Baba, A. S. (2018). Viability of probiotics in dairy products: a review focusing on yogurt, ice cream, and cheese. In A. Datta, M. Fakruddin, H. M. N. Iqbal \& J. Abraham (Eds.), Advances in Biotechnology (Vol. 3). Las Vegas: Open Access eBooks.

Shori, A. B., Aljohani, G. S., Al-Zahrani, A. J., Al-Sulbi, O. S., \& Baba, A. S. (2022). Viability of probiotics and antioxidant activity of cashew milk-based yogurt fermented with selected strains of probiotic Lactobacillus spp. LWT, 153, 112482. http://dx.doi.org/10.1016/j. lwt.2021.112482.

Shori, A. B., Yong, Y. S., \& Baba, A. S. (2020). Effects of herbal yogurt with fish collagen on bioactive peptides with angiotensin-I converting enzyme inhibitory activity. Food Science and Technology. Ahead of print. http://dx.doi.org/10.1590/fst.24020.

Shori, S. A. (2013a). Nutritional and therapeutical values of chickpea water extract enriched yogurt made from cow and camel milk. American Journal of Drug Discovery and Development, 3(2), 47-59. http://dx.doi.org/10.3923/ajdd.2013.47.59.

Silva, C. F. G. D., Santos, F. L., Santana, L. R. R. D., Silva, M. V. L., \& Conceicao, T. D. A. (2018). Development and characterization of a 
soymilk Kefir-based functional beverage. Food Science and Technology, 38(3), 543-550. http://dx.doi.org/10.1590/1678-457x.10617.

Singh, B. P., Bhushan, B. \& Vij, S. (2020). Antioxidative, ACE inhibitory and antibacterial activities of soy milk fermented by indigenous strains of lactobacilli. Legume Science, 2(4), e54.

Slapkauskaite, J., Kabasinskiene, A., \& Sekmokiene, D. (2019). Application of fermented soya as a bacterial starter for production of fermented milk. Czech Journal of Food Sciences, 37(6), 403-408. http://dx.doi. org/10.17221/194/2018-CJFS.

Sridhar, R., Roopa, B., Varadaraj, M., \& Vijayendra, S. (2015). Optimization of a novel coconut milk supplemented dahi-a fermented milk product of Indian subcontinent. Journal of Food Science and Technology, 52(11), 7486-7492. http://dx.doi.org/10.1007/s13197-015-1825-0.

Szparaga, A., Tabor, S., Kocira, S., Czerwińska, E., Kuboń, M., Płóciennik, B., \& Findura, P. (2019). Survivability of probiotic bacteria in model systems of non-fermented and fermented coconut and hemp milks. Sustainability, 11(21), 6093. http://dx.doi.org/10.3390/su11216093.

Taghizadeh, G., Jahadi, M., \& Abbasi, H. (2018). Physicochemical properties of probiotic soy milk chocolate mousse during refrigerated storage. Applied Food Biotechnology, 5(2), 79-86.

Tangyu, M., Muller, J., Bolten, C. J., \& Wittmann, C. (2019). Fermentation of plant-based milk alternatives for improved flavour and nutritional value. Applied Microbiology and Biotechnology, 103(23-24), 9263-9275. http://dx.doi.org/10.1007/s00253-019-10175-9. PMid:31686143.

Tasdemir, S. S., \& Sanlier, N. (2020). An insight into the anticancer effects of fermented foods: a review. Journal of Functional Foods, 75, 104281. http://dx.doi.org/10.1016/j.jff.2020.104281.

Tola, J., \& Mazengia, Y. (2019). Cashew production benefits and opportunities in Ethiopia: a review. Journal of Agricultural and Crop Research, 7(2), 18-25. http://dx.doi.org/10.33495/jacr_v7i2.19.105.

Ustun-Argon, Z. (2019). Phenolic compounds, antioxidant activity and fatty acid compositions of commercial cold-pressed hemp seed (Cannabis Sativa $L$ ) oils from Turkey. International Journal of Scientific and Engineering Research, 10(4), 166-171.

Vanga, S. K., \& Raghavan, V. (2018). How well do plant based alternatives fare nutritionally compared to cow's milk? Journal of Food Science and Technology, 55(1), 10-20. http://dx.doi.org/10.1007/s13197017-2915-y. PMid:29358791.
Wang, J., Li, C., Xue, J., Yang, J., Zhang, Q., Zhang, H., \& Chen, Y. (2015). Fermentation characteristics and angiotensin I-converting enzyme-inhibitory activity of Lactobacillus helveticus isolate $\mathrm{H} 9$ in cow milk, soy milk, and mare milk. Journal of Dairy Science, 98(6), 3655-3664. http://dx.doi.org/10.3168/jds.2015-9336. PMid:25892687.

Wansutha, S., Yuenyaow, L., Jantama, K., \& Jantama, S. S. (2018). Antioxidant activities of almond milk fermented with lactic acid bacteria. Thaiphesatchasan, 42, 115-119.

Weiße, K., Brandsch, C., Zernsdorf, B., Nembongwe, G. S. N., Hofmann, K., Eder, K., \& Stangl, G. I. (2010). Lupin protein compared to casein lowers the LDL cholesterol: HDL cholesterol-ratio of hypercholesterolemic adults. European Journal of Nutrition, 49(2), 65-71. http://dx.doi.org/10.1007/s00394-009-0049-3. PMid:19680704.

Wongthaweewatana, I., Srinophakun, T. R., Saramala, I., \& Kasemwong, K. (2021). Production of milk analogues from rice bran protein hydrolysate using the subcritical water technique. Food Science and Technology, 41(3), 722-729. http://dx.doi.org/10.1590/fst.16520.

Xiudong, X., Ying, W., Xiaoli, L., Ying, L., \& Jianzhong, Z. (2016). Soymilk residue (okara) as a natural immobilization carrier for Lactobacillus plantarum cells enhances soymilk fermentation, glucosidic isoflavone bioconversion, and cell survival under simulated gastric and intestinal conditions. PeerJ, 4, e2701. http://dx.doi.org/10.7717/ peerj.2701. PMid:27867770.

Yeo, S. K., \& Liong, M. T. (2010). Effect of prebiotics on viability and growth characteristics of probiotics in soymilk. Journal of the Science of Food and Agriculture, 90(2), 267-275. http://dx.doi.org/10.1002/ jsfa.3808. PMid:20355041.

Yi, R., Tan, F., \& Zhao, X. (2020). Physicochemical and functional properties of lactobacillus fermented soybean milk. E3S Web of Conferences, 145, 01034

Yuliana, N., \& Rangga, A. (2010). Manufacture of fermented coco milk-drink containing lactic acid bacteria cultures. African Journal of Food Science, 4(9), 558-562.

Zendeboodi, F., Khorshidian, N., Mortazavian, A. M., \& Cruz, A. G. (2020). Probiotic: conceptualization from a new approach. Current Opinion in Food Science, 32, 103-123. http://dx.doi.org/10.1016/j. cofs.2020.03.009. 